\title{
Status update on White-eared Night Heron Gorsachius magnificus in South China
}

\author{
Nycticorax magnifica Ogilvie-Grant, 1899, Ibis (7) 5: 586 \\ JOHN R. FELLOWES, ZHOU FANG, LEE KWOK SHING, BILLY C.H. \\ HAU, MICHAEL W.N. LAU, VICKY W.Y. LAM, LLEWELLYN YOUNG and \\ HEINZ HAFNER
}

\begin{abstract}
Summary
White-eared Night Heron Gorsachius magnificus is probably the most threatened heron species in the world, and the highest priority for heron species conservation. From 1990 to 1998 , there were sightings from only six localities in the wild. There are none in captivity. In 1998 a caged bird was found in a wildlife market in the city of Nanning, Guangxi Zhuang Autonomous Region, People's Republic of China. This finding prompted a 12month survey in 1998-1999 of both markets and potential habitats in Guangxi. Several captured birds provided direct evidence of the existence of small populations in Guangxi and Guangdong Provinces. The respective habitats were surveyed in spring 2000, with emphasis on observations at dusk. The species was seen at two locations. Although some of the captured birds came from highly degraded habitat, the best sites seemed to be in areas near extensive primary forests, with streams, rice fields and marshes. The information obtained will be used to compile a detailed Action Plan designed to prevent the extinction of the species.
\end{abstract}

\section{Introduction}

Since its discovery in the 1890 , there have been only a few confirmed records of White-eared Night Heron Gorsachius magnificus, from scattered localities in China and Vietnam (Styan 1902; La Touche 1913, 1917; Gee et al. 1948; Jonathan Eames pers. comm.). It is probably the most threatened heron species in the world (Kushlan and Hafner 2000), and is listed as Endangered by BirdLife International (2000) and IUCN (Hilton-Taylor 2000). A previous red list assessment (Collar et al. 1994, Baillie and Groombridge 1996) allocated the category Critically Endangered, but recent sightings suggest a population above the threshold for this categorization (M. Crosby in litt. 2001). It is also a Class II protected species in China (Anon. 1996), and listed as Endangered (threat category E) in the China Red Data Book (Wang Sung et al. 1998).

Of the recent records, several were made between 1993 and 1999 in Shennongjia Nature Reserve, Hubei Province (Hu Hongxin 1999 in litt. from M. Crosby 2001). Within southern China there had been three sightings (in June 1990, October 1992 and January 1993), from Longhushan, Xianhu and Nada, and Loxu, all within Nanning District of Guangxi Zhuang Autonomous Region (Zhou 
Fang 1994), followed by five records (four sightings of single adults and one sighting of two young birds) in June 1994 at the District's Damingshan Nature Reserve (Zhou Fang 1996), after which there were no records for several years.

During a survey in Guangxi in May 1998 by Kadoorie Farm and Botanic Garden (KFBG), a conservation charity based in Hong Kong, a juvenile caged bird was found in a market in the city of Nanning (Lee 1998). It was taken into care, before being released in good condition at Damingshan Nature Reserve in August 1998. This reserve is well protected with extensive areas of secondary and primary forest.

The rediscovery of the species in South China prompted KFBG to fund a 12month survey of both markets and potential habitats in Guangxi by Z.F., in collaboration with the Forestry Department of the Guangxi Zhuang Autonomous Region. The full methods and findings will be published elsewhere (Zhou Fang and Hau in prep.) and are only briefly summarized in this paper.

In January 1999, a skin of the species was discovered in the natural history museum of the Chebaling National Nature Reserve, in neighbouring Guangdong Province (Gao Yuren, pers. comm.). The bird was captured nearby in Shixing County on 17 June 1998 by a local hunter, who sold it to the reserve. On 27 August 1999, one of us (L.K.S.) visited the reserve and found two live juvenile birds in captivity. The first was apparently caught by a farmer from Duheng Village on the night of 11 August, in an agricultural field near the main stream outside the reserve's eastern entrance. Its left wing was broken and it was later euthanized, its skin being retained by the reserve museum. The second bird was caught on the night of 25 August by the same farmer, at the same site. This individual was released on 27 August at the main stream just outside the museum.

KFBG notified the Heron Specialists Group (which liaises with IUCN, Wetlands International and BirdLife International on heron conservation) of these developments. It was subsequently decided to launch a joint field survey in southern China in spring 2000, based mainly on results obtained by Z.F. in 19981999.

\section{Methods}

The 12-month survey 1998-1999

Questionnaires and photographs of all herons of the region (including one of an adult mounted White-eared Night Heron) were mailed to members of the Guangxi Zoology Society, Forestry Department offices, Environmental Protection Agency offices, biology teachers and known naturalists in all counties of Guangxi. The questionnaire stated that true information on the status of the birds would be rewarded. The importance of the species was also stated and a warning was included to discourage hunting. The questionnaire also served as an educational leaflet. Newspapers, magazines and television cooperated in highlighting the urgent need to improve knowledge on the distribution and habitats used by the species for its effective conservation. Field surveys were conducted in areas where the species had been reported in the past and in areas where responses to the questionnaires gave plausible evidence of its existence. Local hunters and 
medicinal plant collectors were interviewed and asked to identify White-eared Night Heron from a selection of pictures showing different heron species.

The animal markets in Nanning and other localities were visited regularly. Any White-eared Night Herons on sale were purchased for rehabilitation, and their origins traced as far as possible.

\section{The spring 2000 field survey}

The results of the 12-month survey were instrumental in the planning of the subsequent field survey. Most of our time was devoted to field investigation. In addition local people were interviewed using pictures of herons for reference.

Existing information on recently trapped or shot individuals supported observations in the literature (e.g. Kushlan and Hafner 2000) that White-eared Night Heron is a forest species. Observation priority was given to sites where individuals had recently been trapped, shot or reliably reported, some of which had highly degraded habitat (see list of sites below). Attention was also paid to primary forest areas nearby, with streams, rice fields and marshes, which constituted promising foraging areas.

Although published information on the behaviour of White-eared Night Heron is virtually non-existent, we assumed that, like the other Gorsachius species, it is mainly active at night and rests during the day. During the chick-raising period other night heron species can be seen searching for food in daylight but we were too early in the season for this, and adjusted our methodology to emphasize crepuscular observations, particularly at dusk when the chance of seeing birds moving to foraging areas was considered highest.

At dusk, observations were made from strategic points overlooking potential roosting and feeding habitats: streams, paddy fields, fish ponds and marshes adjacent to forested slopes. Detection was based on both visual and auditory contact; observations started at least one hour before, and lasted until one hour after, sunset. At dawn, observations started one hour before, and ended one hour after, sunrise. In order to cover as much ground as possible, we generally split into at least three groups of observers, each operating simultaneously in different sectors of a potential nesting and resting area. During daytime, potential resting and nesting sites were patrolled with the aim of characterizing habitats, detecting nesting activity and flushing any birds at rest.

\section{Sites surveyed}

Eight sites in southern Guangxi and one site in northern Guangdong were surveyed (Figures 1 and 2). The characteristics of each site are described in Table 1.

\section{Results}

The 12-month survey 1998-1999

Although there were no direct observations of White-eared Night Heron in the wild during this survey, it provided an invaluable indication and firm evidence of the occurrence of the species. Dead and trapped birds provided the direct 

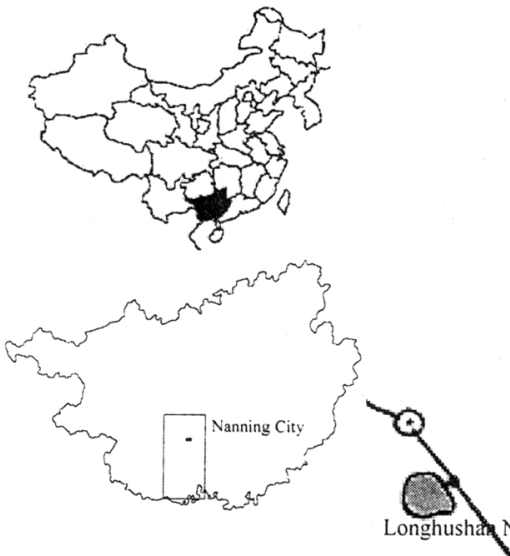

Xianhu Reservoi

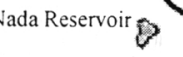



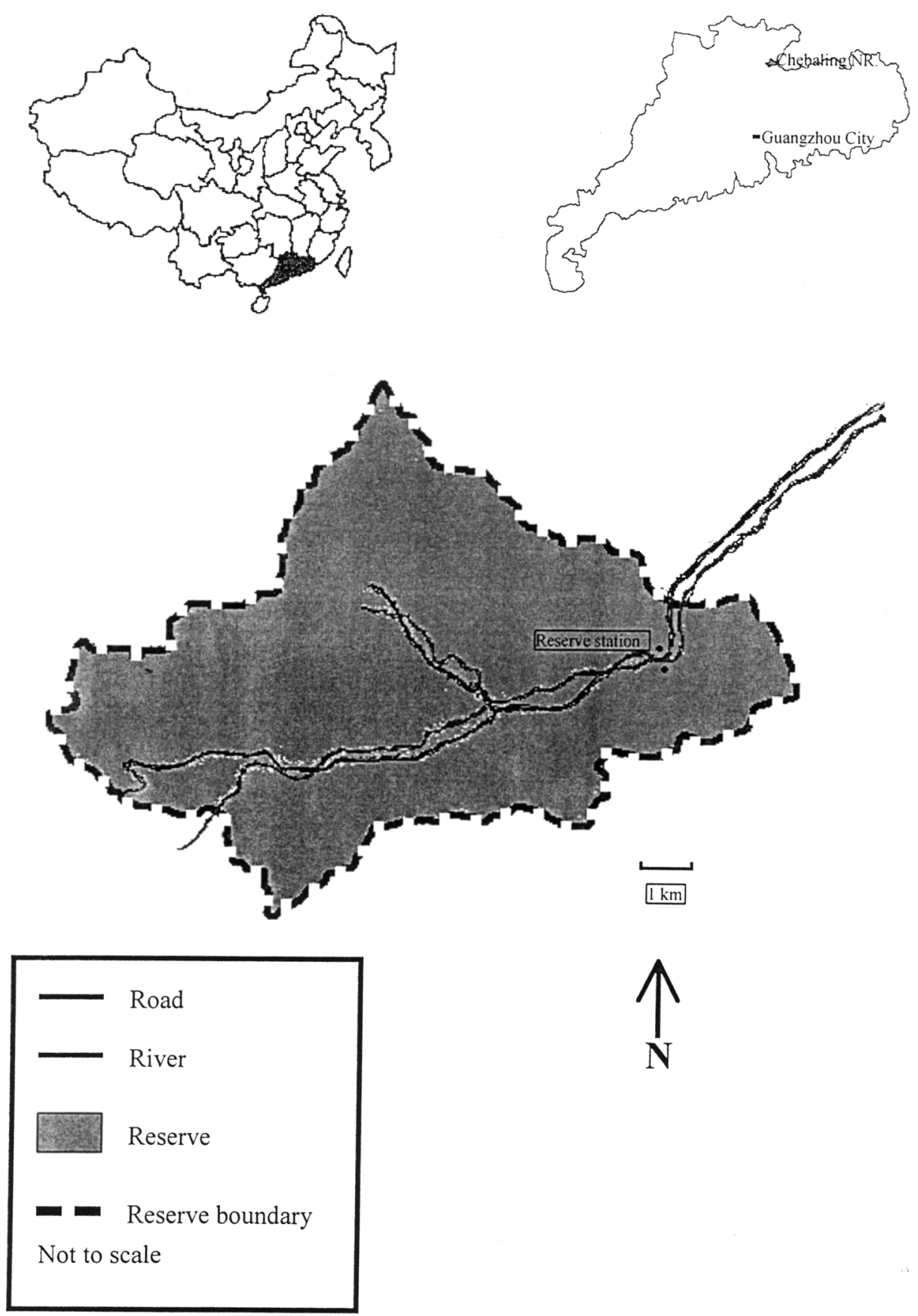

Figure 2. Site surveyed for White-eared Night Heron Gorsachius magnificus in Guangdong Province, China in spring 2000. 
Table 1. Details of sites visited in surveys of White-eared Night Heron Gorsachius magnificus in Guangxi Zhuang Autonomous Region and Guangdong Province, China, in spring 2000.

Site and habitat description

Previous This

records survey

Nazao Cun ${ }^{\mathrm{a}}$, Shangsi County, Guangxi $\left(22^{\circ} 10^{\prime} \mathrm{N}, 108^{\circ} 05^{\prime} \mathrm{E}\right)$

Altitude $180 \mathrm{~m}$. Hillside covered by dense Pinus massoniana plantation, with young Liquidambar formosana saplings in part, and common shrub species such as Melastoma sanguineum and Rhodomyrtus tomentosa. Flat area with a small, low-gradient river and rice paddies. Surveyed on $29 \mathrm{March}$, including a visit to an abandoned Gorsachius heronry in a P. massoniana plantation, and a dusk watch by the river. Part of the Shangsi White-eared Night Heron Reserve, declared in 2000.

Biannian Village, Shangsi County, Guangxi $\left(22^{\circ} 10^{\prime} \mathrm{N}, 108^{\circ} 20^{\prime} \mathrm{E}\right)$

Altitude $200 \mathrm{~m}$. Fengtinghe Reservoir near Datang was surrounded by P. massoniana plantations and patches of secondary forest. The village had extensive areas of rice paddies close to partially forested hills. Surveyed on 30 March, following confirmed trapping of a White-eared Night Heron in 1999. Part of the Shangsi White-eared Night Heron Reserve.

Shiwandashan Forest Park, Shangsi County, Guangxi $\left(21^{\circ} 30^{\prime}-22^{\circ} 08^{\prime} \mathrm{N}, 107^{\circ} 30^{\prime}-\right.$ $108^{\circ} 30^{\prime}$ E)

Altitude $380 \mathrm{~m}$. Vegetation consisted of extensive areas of primary and secondary forest with large rocky streams. Surveyed on 31 March to I April, with dusk and dawn watches by the streams.

Nahuang Cun, Fusui County, Guangxi (22 ${ }^{\circ} 11^{\prime} N$, $\left.107^{\circ} 50^{\prime} E\right)$

Altitude $250 \mathrm{~m}$. Young Pinus massoniana pine and Phyllanthus embalica bamboo plantations on the hills, and a feng shui wood in the village, with some remnant secondary forest in ravines. There were also many fish ponds and rice paddies, and a marsh; villagers reported having seen White-eared Night Herons in these habitats, and a dead juvenile was confirmed by Z.F. from the abandoned heronry in a secondary forest. Visited on I April, with a dusk watch at the various wetland habitats. Part of the Fusui White-eared Night Heron Reserve, declared in 1999.

Longhushan, Longan County, Guangxi $\left(22^{\circ} 42^{\prime} \mathrm{N}, 107^{\circ} 30^{\prime} \mathrm{E}\right)$

Altitude $230 \mathrm{~m}$. Good secondary forest and a low-gradient stream in the Longhushan Nature Reserve, and small streams and rice paddies outside the reserve. Near the site of a confirmed sighting by Z.F. in 1990. Surveyed on 23 April, with dusk and dawn watches.

Xianhu Reservoir, Wuming County, Guangxi $\left(23^{\circ} 26^{\prime} \mathrm{N}, 108^{\circ} 25^{\prime} \mathrm{E}\right)$

Altitude $200 \mathrm{~m}$. The reservoir was surrounded by pine plantation. Marshes formed from abandoned paddies at the edge. Visited during the daytime on 3 April, following confirmed sighting by Z.F. in 1992.

Nada Reservoir, Wuming County, Guangxi $\left(23^{\circ} 28^{\prime} \mathrm{N}, 108^{\circ} 27^{\prime} \mathrm{E}\right)$

Altitude $200 \mathrm{~m}$. The reservoir was surrounded by pine plantations, with rice paddies and streams lower in the valley. Visited on 3 April, with a dusk watch. Damingshan, Wuming County, Guangxi $\left(23^{\circ} 24^{\prime}-23^{\circ} 30^{\prime} \mathrm{N}, 108^{\circ} 20^{\prime}-108^{\circ} 24^{\prime} \mathrm{E}\right)$

Altitude 150 to $1,700 \mathrm{~m}$. Extensive primary and secondary forests with many gorges and streams in the Damingshan Nature Reserve. Visited on 4-5 April, with dusk and dawn watches at various points in the forest, following confirmed sightings of single adults and two young birds by Z.F. in June 1994.

Chebaling, Shixing County, Guangdong $\left(24^{\circ} 42^{\prime} \mathrm{N}, 114^{\circ} 10^{\prime} \mathrm{E}\right)$

Altitude 375 to $1,255 \mathrm{~m}$. Extensive primary forest in the core area of Chebaling National Nature Reserve, with secondary forest, pine plantation and agricultural fields in other parts of the reserve. There were also deep gorges and many small rivers in the reserve. Visited on 7-11 April, following captures of birds by residents in 1999 .

${ }^{a}$ Cun is the smallest village unit in South China, several cuns forming a village.

$\bullet$, firm record; o, unconfirmed report. 
evidence. In 1999 Z.F. identified a partly decomposed body of a juvenile at a heron nest site near Nahuang Cun, in Fusui County. According to villagers this colony was not active in 1999 but had been occupied by herons in 1998. According to Z.F. (unpubl. data), the eggshell remains which were white with a pale greenish tinge, and from relatively large eggs, belonged to a Gorsachius species. It is therefore suspected that the majority of the birds were Malayan Night Herons, the only Gorsachius species known to breed occasionally in small colonies (Hancock and Kushlan 1984, Hancock 1999). Also in 1999, two live juvenile White-eared Night Herons were found in wildlife markets in Guangxi: one in Shajing Town (24 June 1999), a suburb of Nanning, and one in Datang Village (28 August 1999), which was known to have been caught from Fengtinghe Reservoir. Z.F. bought these birds with the intention of rearing them. One died in captivity, but the second bird, in excellent condition after two months, was released near Nahuang Cun (see Figure 1) in an area recently designated as Fusui White-eared Night Heron Reserve. Finally one injured adult, shot by villagers near the Fengtinghe Reservoir, was brought to the Shangsi Forestry Bureau in December 1999. The bird later died in captivity; the preserved specimen is held at the Forestry Bureau.

\section{The spring 2000 field survey}

The suspected nesting site at Nazao, now abandoned, consisted of Pinus massoniana plantation, some $50 \mathrm{~m}$ from a stream up to $60 \mathrm{~m}$ wide. Trees were 10 to 12 $\mathrm{m}$ in height and $14 \mathrm{~cm}$ in diameter at breast height $(\mathrm{DBH})$. Some 40 nests were found, all between 7 and $10 \mathrm{~m}$ above the ground. The confirmed nesting site at Nahuang Cun, also abandoned, was in a shallow ravine on a shrub-covered hillside. The site was within $500 \mathrm{~m}$ of paddy fields and a stream in the plain below the hill. The trees were mostly young broadleaf species, including Breynia fruticosa, Litsea glutinosa, Cinnamomum porrectum and Macaranga denticulata. The tallest were $12 \mathrm{~m}$ in height and $11 \mathrm{~cm}$ DBH. Some 18 nests were observed, from 4 $\mathrm{m}$ to $10 \mathrm{~m}$ above the ground. At both sites the nests were about $2 \mathrm{~m}$ from the treetops, positioned against the trunk; each consisted of several hundred twigs arranged in a simple flat platform. In each of these two colonies, egg-shell remains indicated a Gorsachius species (Z.F. unpubl. data). Japanese Night Heron Gorsachius goisagi nests solitarily, but in favourable conditions nests may be quite close together (Hancock and Kushlan 1984). All the previous observations of White-eared Night Heron refer to single individuals or pairs and it is strongly suspected that this species usually nests solitarily. The nest density in the two colonies was high and it is unlikely that all the nests belonged to this species.

During the field survey the species was seen four times in two localities, always very briefly, in flight, and after sunset. The first observation was made on 30 March at 19h30 (sunset was at about 19h15) near Biannian Village in Guangxi (see Figure 1). The white pattern on the head and throat was clearly visible. At the second site, adjacent to Chebaling National Nature Reserve in Guangdong, two birds were observed on three consecutive evenings (8, 9 and 10 April) from the same two observation points separated by about $80 \mathrm{~m}$. The birds appeared at $18 \mathrm{~h} 44$ on 8 April, 19ho1 on 9 April, and at 19 hoo on 10 April (sunset here was at about $18 \mathrm{~h} 45$ ). Because of the dim light the white pattern around the 
ear was not visible; however the contrasting white pattern along the throat was diagnostic. We succeeded in photographing one of the birds on 10 April. At both localities, it was impossible to tell whether they were second year birds (hatched in 1999) or older individuals. We noted that, unlike most Black-crowned Night Herons Nycticorax nycticorax, the birds were totally silent when flying out to the feeding grounds.

At other sites, the presence of the species could not be confirmed. At Nazao Cun and Nahuang Cun it is likely that previous nesting sites were abandoned due to local hunting pressure, coupled with extended drought at the latter site.

\section{Discussion}

\section{Habitat and behaviour}

Sites in southern Guangxi where White-eared Night Heron is confirmed to survive were highly degraded after centuries of human habitation. All suspected daytime retreats were in forest within $500 \mathrm{~m}$ of streams or inundated fields. Nesting has been confirmed in a secondary forest ravine at Nahuang Cun, and suspected in a pine plantation at Nazao Cun. The roost site at Chebaling was also secondary forest. Thus we can tentatively conclude that pristine habitat is not essential for the species. However, all the confirmed sites, in both Guangxi and Guangdong, were no more than some $40 \mathrm{~km}$ from areas of extensive primary forests, at Shiwandashan Nature Reserve and Forest Park, Damingshan Nature Reserve and Chebaling National Nature Reserve respectively. Although the birds can clearly nest and feed in more degraded habitats, it is likely that such inaccessible forests have been essential refuges from hunting pressure over the centuries, from which more populated areas might have been recolonized after local extirpation. It is also possible that birds in the more pristine forest habitat have a relatively high breeding success, reinforcing the population of nearby degraded habitats which may act as 'sinks'. The optimal habitat is probably primary forest with adjoining rice fields, marshes and slow-flowing streams that constitute good foraging areas. The species is found exclusively in hilly and mountainous areas, probably because there are no forests remaining in low-lying flat areas. To our knowledge the species has always been recorded below 1,300 $\mathrm{m}$ altitude.

The known heron colonies believed to contain White-eared Night Herons were small: we saw two abandoned heronries of 40 and 18 nests respectively. It is suspected that at least one of these comprised mainly Malayan Night Herons, suggesting that mixed-species breeding may occur. Colonies apparently had a high turnover rate, probably due to heavy disturbance by humans.

\section{Distribution}

White-eared Night Heron survives in at least two areas of southern China, and in western Hubei, in central China. In all three areas its existence must be considered precarious. Its occurrence elsewhere remains uncertain. While there have been no recent reports from other parts of its historical range, from Zhejiang, Jiangxi and Fujian Provinces to northern Vietnam (La Touche 1934, Cheng TsoHsin 1987) there is also a clear need for renewed survey effort. This should con- 
centrate on forested areas of Guangxi, Guangdong, Hainan, Hunan, Jiangxi, Fujian and Zhejiang.

\section{Major threats}

Hunting pressure is intense in agricultural areas of the species' range and represents a major threat. Hunting methods involve a combination of shooting and trapping with baited nooses at the nest site or feeding site. The suspected practice of joining colonies of other night herons to breed, while having possible benefits against some predators, may also have costs. Colonies, if not in remote areas, are generally quickly detected by local people and stand little chance of lasting long, the chicks being harvested and the adults shot. The nesting period is therefore an extremely vulnerable stage for colonial herons. There seems to be a strong demand for local consumption of birds in general. Evidence suggests that Whiteeared Night Heron is not currently targeted specifically, but is under the same high hunting pressure as all edible wildlife in the region.

Although deforestation has been curtailed since 1998, the forest remaining in southern China is still threatened by clearance. In addition, in degraded habitats (especially in Guangxi) much of the forest area is a monoculture of pine, highly susceptible to pathogens such as the pinewood nematode Bursaphelenchus xylophilus, which destroyed many Pinus massoniana monocultures in Guangdong and Hong Kong in the 1980s to 1990s (Dudgeon and Corlett 1994), and is spreading towards Guangxi. Deforestation and fragmentation of the habitat are serious threats to nesting and roosting habitat, both directly and through increased susceptibility to wild fire in the dry season.

Although there is no direct evidence of contaminants affecting heron foraging, levels of pesticide and fertilizer use in China are extremely high, and low bird numbers have been attributed in part to their impacts on insects, fish and amphibians (e.g. MacKinnon et al. 1996). Rice fields and the associated irrigation systems are used by White-eared Night Herons as foraging areas. The high costs of fertilizers and pesticides have limited their use in some of the poorer rural areas and this may have benefited the integrity of wetland ecosystems. It would be interesting to compare variation between areas supporting White-eared Night Herons and others where agriculture is more intensive.

\section{Conservation steps}

To some extent, successful conservation of the species will depend on an improved understanding of its ecological requirements and annual movement patterns, and further study is therefore essential. For example, it is not currently known whether White-eared Night Herons use different habitats outside the breeding season. However, conservation action cannot wait for these gaps in our knowledge to be filled. Based on recent surveys we can draw up a preliminary list of priority sites, which can be modified later as knowledge increases. In recent years strong commitment to conserving the species has been shown by Guangxi Forestry Department, and county governments, leading to the establishment of Fusui White-eared Night Heron Reserve and the Shangsi White-eared Night Heron Reserve in southern Guangxi. In the light of recent findings, Chebaling 
National Nature Reserve and the Guangdong Forestry Department have also expressed an intention to step up conservation efforts.

In view of the evident precariousness of the detected populations, we would urge that no further specimens are taken from the wild. Effective conservation at these sites will call for a sensitive combination of community development, education, habitat management and law enforcement. The government officials concerned accept the difficulties of implementing this protection, and have invited assistance. To this end we propose to compile a survival plan for the species, incorporating elements of the plans for Fusui (Anon. 1999a) and Shangsi (Anon. 1999b) and highlighting the urgent steps and resources needed to conserve the species. We hope that this work may contribute to saving White-eared Night Heron from extinction.

\section{Acknowledgements}

This study has been financed by Kadoorie Farm and Botanic Garden. The authors thank the Forestry Departments of Guangxi Zhuang Autonomous Region and Guangdong Province for their support and collaboration, and especially the directors and staff of the two Wild Animals and Plants and Nature Reserve Management Stations. We are grateful to the Shangsi government for its hospitality. We also thank our colleagues Mr Wang Ruijiang and Mr Cheng Jisheng (South China Institute of Botany), who added greatly to the survey team. Heinz Hafner's participation in the survey was kindly supported by the Station Biologique de la Tour du Valat.

\section{References}

Anon. (1996) Rare and endangered animals of China. The People's Republic of China Endangered Species of Wild Fauna and Flora Import and Export Administrative Office. Shanghai: Shanghai Scientific and Technical Publishers.

Anon. (1999a) Proposal to implement conservation of the White-eared Night Heron in Fusui County. Fusui Government Issue No. 55. (In Chinese.)

Anon. (1999b) Proposal to implement conservation of the White-eared Night Heron in Shangsi. Shangsi Government Issue No. 41. (In Chinese.)

Baillie, J. and Groombridge, B. (eds.) (1996) 1996 IUCN Red List of threatened animals. Gland, Switzerland and Cambridge, U.K.: IUCN.

BirdLife International (2000) Threatened birds of the world. Barcelona: Lynx Editions and Cambridge: BirdLife International.

Cheng, Tso-Hsin (1987) A synopsis of the avifauna of China. Beijing: Science Press and Hamburg and Berlin: Paul Parey.

Collar, N.J., Crosby, M.J. and Stattersfield, A.J. (1994). Birds to watch 2. The world list of threatened birds. Cambridge: BirdLife International (BirdLife Conservation Series 4.)

Dudgeon, D. and Corlett, R. (1994) Hills and streams: An ecology of Hong Kong. Hong Kong: Hong Kong University Press.

Gee, N.G., Moffat L.I. and Wilder, G.D. (1948) A tentative list of Chinese birds. Shanghai: Western Art Gallery.

Hancock, J. (1999) Herons and egrets of the world. London: Academic Press.

Hancock, J. and Kushlan, J. (1984) The herons handbook. London: Croom-Helm and New York: Harper and Row. 
Hilton-Taylor, C. (compiler) (2000) 2000 IUCN Red List of threatened species. Gland, Switzerland and Cambridge, U.K.: IUCN.

Kushlan, J.A. and Hafner, H. (eds.) (2000) Heron conservation. London: Academic Press.

La Touche, J.D.D. (1913) Untitled. Ibis ser. 10: 282.

La Touche, J.D.D. (1917) Untitled. Ibis ser. 10:562.

La Touche, J.D.D. (1934) A handbook of the birds of eastern China, 2, pp. 401-496. London: Taylor and Francis.

Lee, K.S. (1998) White-eared Night Heron Gorsachius magnificus on sale in a Nanning market. OBC Bulletin 28: 13.

MacKinnon, J., Meng, S., Cheung, C., Carey, G., Zhu, X. and Melville, D. (1996) A biodiversity review of China. Hong Kong: World Wide Fund for Nature International China Programme.

Styan, F.W. (1902) On the occurrence of Nycticorax magnifica in the Anwhei Province of China. Ibis 8 (2).

Wang Sung, Zheng Guang-Mei and Wang Qi-Shan (1998) China Red Data Book of endangered animals: Aves. Beijing: Science Press.

Zhou Fang (1994) A preliminary observation on the Chinese Night Heron Gorsachius magnificus. P. 167 in Waterbird Research in China, Waterbird Specialist Group of Chinese Ornithological Association, East China Normal University Press.

Zhou Fang (1996) White-eared Night Heron in Guangxi. Conservation fund in action. Oriental Bird Club Bulletin 23: 8-9.

JOHN R. FELLOWES ${ }^{1}$, LEE KWOK SHING, BILLY C.H. HAU, MICHAEL W.N. LAU and VICKY W.Y. LAM

Kadoorie Farm and Botanic Garden, Lam Kam Road, Tai Po, New Territories, Hong Kong Special Administrative Region, China.

E-mail: scbt@kfbg.org.hk

\section{ZHOU FANG}

College of Animal Science, Guangxi University, 13 Xiuling Road, Nanning City, Guangxi Zhuang Autonomous Region, China. Postal code: 530005

\section{LLEWELLYN YOUNG}

World Wide Fund for Nature Hong Kong, Mai Po Marshes Nature Reserve, Yuen Long, New Territories, Hong Kong Special Administrative Region, China.

E-mail: deblew@netvigator.com

\section{HEINZ HAFNER}

Station Biologique, La Tour du Valat, Le Sambuc, F-13200-Arles, France.

E-mail: hafnerhp@aol.com

${ }^{1}$ Author for correspondence; current address: 109 The Manor Drive, Worcester Park, Surrey KT4 7LN, U.K. E-mail: jr.fellowes@virgin.net

Received 15 July 2000; revision accepted 29 January 2001 